\title{
The Effect of Training Method and Motor Ability on Javelin Throw Technique
}

\author{
Tri Setyo Guntoro ${ }^{1}$ \\ ${ }^{1}$ Faculty of Education, Universitas Cenderawasih, Indonesia \\ Correspondence: Tri Setyo Guntoro, Faculty of Education,Universitas Cenderawasih, Kampus UNCEN Waena, \\ Jl. Camp Wolker, Jayapura, Indonesia. E-mail: tsguntoro09@gmail.com
}

Received: February 12, 2014 Accepted: February 20, 2014 Online Published: February 28, 2014

doi:10.5539/ass.v10n5p159 URL: http://dx.doi.org/10.5539/ass.v10n5p159

\begin{abstract}
The objective of this study is to find out the effect of training method and level of motor ability on the javelin throw technique. The sample for the research was 48 students randomly selected from the sports program at the Faculty of Education, Universitas Cenderawasih, Papua. The research reveals that method of training has an effect on the technique of javelin throw. Plyometrics training method gives better effect than conventional training method. Results also showed that students who have high motor ability benefits more with plyometrics training method while students with low motor ability benefits better with conventional training method. Finally, this study proves that there is a positive interaction between training method and motor ability on javelin throw technique.
\end{abstract}

Keywords: training method, motor ability, javelin throw technique

\section{Introduction}

Along with the recent developments in the era of globalization, marked by the rise of global economic and political systems, as well as rapid advancement in science, good performance in sports is becoming more intense and is seek after for national and international pride. Athletics are intrinsically competitive physical activity, which includes several events involving basic movement skills such as walking, running, jumping and throwing. Although these basic movements seems simple but behind this simplicity needs a synergistic coordination of the various elements of the body to make the right and perfect moves, resulting in an achievement.

In 1980 and 1990 the province of Papua had great contribution in providing budding national athletes, especially in distance running and throwing events. Papua is currently experiencing stagnant conditions in coaching track and field athletes in general and in particular, the javelin throw. This can be seen from the number of young athletes being coached by senior athletes in Papua is rather low. Based on observations in Papua from 1992 to 2001 the public interest, especially among students and young people to athletics is very low. Majority of athletes today focus in short and medium distance events. Long distance athletes are minimal and the general public mostly run for fitness, but only started doing so when they are elderly. Facilities for field events were untreated due to it being underutilized, which will only be groom when a championship is just around the corner. Although javelin is an event that has always seen an athlete from Papua competing in every championship both nationally and internationally, but unfortunately resources for javelin especially coaches and athletes are low. This issue could indirectly hinder the progress or development of the javelin.

Javelin throw involve the running movement, crossing the leg and with one hand carrying the javelin and throwing it for distance. The technique in throwing a javelin involves the following phases: run, transition, and throw. When an athlete is able to master the basic techniques properly and supported by high-motor skills will result in optimal performance and vice versa. To produce optimal performance, javelin throw must be supported by several components, among others; quality coach, a gifted athlete, advanced exercise program, physical condition and mental health.

Method is a concept or a similar form of exercise or activity resembling circumstances which often occur in a real situation. The javelin throw training in Papua typically use the conventional methods. The conventional method is an approach that commonly emphasizes the use of weight training by the coaches. This training method is less likely to contribute to increased achievement of Papua javelin athlete. 
The achievements of Papua athletes in any activity are not increasing. The complaint was also expressed by Papua javelin throw coaches. Therefore, there should be a breakthrough in using training methods that can fully develop the potential of javelin throwers which is the plyometrics training methods. Plyometrics is a form of exercise to improve the quality of athletes in the form of power and speed. With the application of this method a synergy occurs between increasing explosive power of arm muscles, legs and body technique that produces optimal throw. The throw, using this technique will be maximized if supported by high-motor skills.

Performance of motor skills is the capacity of a person to perform an assortment of physical activity. An individual with high motor skills will certainly be able to carry out movement tasks successfully. On the other hand, a person with low motor skills will not be able to perform movement tasks properly. Based on the problems above, it is necessary to study and practice using motor skills for javelin throws technique. The methods used in this study consist of; conventional methods of training and plyometrics training methods whereas motor skills are the independent variables.

\section{Methodology}

The main focus of the research is the javelin throw technique, namely the ability to carry the javelin while running, crossing the legs and throwing the javelin. The method consists of plyometrics training method and conventional training methods. Besides the training methods, another indicator to achieve optimal training results is the samples' psychomotor ability. Treatment in this study conducted over eight weeks, meeting three times each week resulting in overall 24 meetings.

To achieve the research objectives stated, an appropriate research methods need to be determined. Thomas and Nelson (1985) assert the superiority of experimental method over other types of research. Therefore, the research method used in this research is experimental design using $2 \times 2$ factorial, involving one independent variable with two levels which is plyometrics training method and conventional training methods. A categorical variable also with two levels which is high and low motor skills, and the dependent variable is the javelin throw technique.

Sampling technique using randomized design, whereby 48 students were chosen from a population of 92 . The 48 students were tested and divided into high psychomotor skills and low psychomotor skills. Each group were then further divided into two whereby 12 samples in each group were given plyometrics training method and the other 12 were trained using the conventional training method. Table 1 shows the grouping of the sample.

Table 1. Grouping of samples

\begin{tabular}{|c|c|c|c|}
\hline Motor Ability (B) & Exercise (A) & Plyometrics $\left(\mathrm{A}_{1}\right)$ & Conventional $\left(\mathrm{A}_{2}\right)$ \\
\hline $\operatorname{High}\left(\mathrm{B}_{1}\right)$ & & 12 & 12 \\
\hline Low $\left(\mathrm{B}_{2}\right)$ & & 12 & 12 \\
\hline Total & & 24 & 24 \\
\hline
\end{tabular}

\section{Results}

Results of ANOVA showed that there is a significant difference in javelin throwing technique between the two methods of training $(\mathrm{F}=7.76, \mathrm{p}>0.05)$. Interaction between training methods and motor skills also significantly influence javelin throw technique $(\mathrm{F}=50.85, \mathrm{p}>0.05)$. Since there is a significant influence, further post hoc test were conducted.

Based on the results of post hoc tests, it can be concluded that:

1) The first research hypothesis which states that students who receive plyometrics training methods (A1) for javelin throw technique achieve significantly higher score than students who receive conventional training methods (A2), is accepted.

2) The second research hypothesis which states that the javelin throw technique scores of students with high psychomotor skills will significantly benefits more from plyometrics training method (A1B1) than students who receive conventional training methods (A2B2) is accepted. 
3) The third research hypothesis which states that the scores for javelin throw technique of students with poor psychomotor skills trained using plyometrics methods (A1B2) is lower than students who receive conventional training methods (A1B2) is accepted.

4) The fourth research hypothesis which states that there is an interaction between the influence of training methods and motor abilities of the students in the javelin throwing training. Analysis shows that students achievement in javelin throw technique is influenced by the interaction between the training methods used and psychomotor skills of students. $(\mathrm{F}=5085, \mathrm{p}>0.05)$

\section{Conclusion}

Based on the data analysis and results obtained, the conclusion of this study is as follows:

1) The first research hypothesis states that the javelin throw technique scores of students who were trained with plyometrics (A1) is higher than those trained with conventional training methods (A2) is accepted. Training methods used on the groups give different effects on mastery of javelin throw techniques, where plyometrics training methods are far superior to conventional training methods. Therefore, it can be concluded that to achieve the objectives of javelin throw technique training, plyometrics training method is more effective than conventional training methods. Plyometrics is a training method that leads to the achievement of training objectives efficiently ie mastering skills through the development of rapid and dynamic movements in accordance with the purpose of the exercise.

2) The second hypothesis states that javelin throw technique scores of students who were trained using the plyometrics method (A1B2) is higher than those trained with conventional training methods (A2B2) for students who have high motors skills. Based on the results of the data analysis, the effects of plyometrics training is superior to that of conventional training methods for javelin throw technique for samples with high levels of psychomotor skills. This study therefore concluded that plyometrics training methods are proven to give athletes opportunities in exploring the motion in accordance with the demands of the task.

3) The third hypothesis states that the javelin throw technique scores of students who were trained with plyometrics (A1B2) is lower than those trained with conventional methods (A2B2) for students with poor motors skills. Results showed that the training methods have different effects on the javelin throw technique for groups with low levels of psychomotor skills. This supports the proposed theory of psychomotor skills development by Rosli Lutan, which states that basic motor skills will later serve as the foundation for the development of other specialized skills. Thus, this means that psychomotor skills will better support the mastery of techniques and the demanding needs of the highly potential plyometrics exercises to improved precise skill movements. On that basis, if the motor skills are lacking, then the response to the mastery of techniques using plyometrics training methods is relatively low.

4) The fourth hypothesis states that there is an interaction between training methods and psychomotor abilities in improving javelin throw technique. This hypothesis was accepted since there is a significant interaction between methods of training with psychomotor skills of students in improving javelin throw techniques. Students with high psychomotor skills and trained with plyometrics training methods achieve higher in javelin throw ability when compared to the high psychomotor skilled group that was trained with conventional training methods. This shows that the effect of plyometrics training methods relates to the psychomotor skills of students who attended the training. In contrast, students who have low psychomotor skills and trained using the plyometrics methods scored lower in javelin throw techniques achievements when compared to the group of students with low psychomotor skills and trained with conventional training methods.

In conclusion, plyometrics training is suitable for improving javelin throw technique. As such, coaches should look over this matter and to design a training program using the most effective training method which would increase the athletes' performance.

\section{References}

Anon. (n. d.). Track and Fields Techniques for Girls and Woman.

Arnheim, D. D. (1985). Modern Principles of Athletic Training. Missouri: Mosby College Publishing.

Astrand, P. O., \& Rodhal, K. (n. d.). Texbook of Work Physiology. New York: McGraw Hill Book Company.

Ballesteros, J. M. (1993). Basic Coaching Manual. London: IAAF.

Bompa, T. O. (1994). Theory and Methodology of Training (3rd ed.). Iowa: Kendal/Hunt Publishing Company.

Brooks, G. A., \& Fahey, T. D. (1987). Exercise Physiology: Human Bioenergetics and Its Application. New York: 
John Willey \& Sons.

Burton, A. W. (1998). Movement Skill Assesment. Iowa: Human Kinetics.

Chu, D. A. (1992). Jumping Into Plyometrics. California: Castro Valley.

Fox, E. L. (1993). Sport Physiology. Tokyo: WCB Brown Saunders Book.

Fox, E. L., Bowers, R. W., \& Foss, M. L. (1988). Physiological Basis of Physical Education and Athletics. Philladelphia: Saunders College Publishing.

Glass, G. V., \& Hopkins, K. D. (1984). Statistical Methods in Education and Psychology. Englewood Cliffs: Prentice Hall.

Gobbard, C., Leblanc, B., \& Lowy, S. (1987). Physical Education for Children: Building the Foundation. New Jersey: Prentice Hall Inc, Englewood Cliffs.

Guyton, A. C. (1991). Textbook of Medical Physiology (8th ed.). Philadelphia: WB Saunders Company.

IAAF. (1998). Pendidikan Pelatih dan Sistem Setifikasi Event Lempar Lembing. Jakarta: PASI.

Johnson, C. (2000). Javelin Throwing. London: British Amateur Athletic Board.

Luddin, P. (1986). Utilizing Plyometric in Modern Athletics and Coaching. Sydney: Australia Post Publication.

McArdle, W. D. (1981). Exercise Physiology. Philadelphia: Lea and Febiger.

Radcliffe, F. S., \& Forentinos, R. C. (1985). Plyometric. Ilinos: Human Kinetic Publisher Inc.

Ritzdorf, W., \& Muller, H. (2000). Run, Jump and Throw the IAAF Guide To Teaching Athletics. Colgne: IAAF.

Rothstein, A. L. (1985). Research, Design and Statistics for Physical Education. New Jersey: Prentice Hall, Inc.

Thomas, J. R., \& Nelson, J. K. (1985). Introduction to Research in Health, Physical Education, Recreation and Dance. Champaign Illinois: Human Kinetics Publisher.

Wagner, D. R., \& Kocak, M. S. (1997). A Multivariate Approach to Assessing Anaerobic Power Following a Plyometric Training Program. Journal of Strength and Conditioning Research. Colorado: NSCA.

\section{Copyrights}

Copyright for this article is retained by the author(s), with first publication rights granted to the journal.

This is an open-access article distributed under the terms and conditions of the Creative Commons Attribution license (http://creativecommons.org/licenses/by/3.0/). 